\title{
Cost structure and profitability of Assaf dairy sheep farms in Spain
}

\author{
M. J. Milán, ${ }^{*}$ F. Frendi, ${ }^{*}$ R. González-González,† and G. Caja* \\ *Grup de Recerca en Remugants (G2R), Department de Ciència Animal i dels Aliments, Universitat Autònoma de Barcelona, 08193 Bellaterra, \\ Spain \\ †Gestión Empresarial de Ovino, 34004 Palencia, Spain
}

\section{ABSTRACT}

Twenty dairy sheep farms of Assaf breed, located in the Spanish autonomous community of Castilla y León and included in a group receiving technical support, were used to study their production cost structure and to assess their economic profitability during 2009. On average, farms had $89.2 \pm 38.0$ ha (own, $38 \%$ ), $592 \pm$ 63 ewes, yielded $185.9 \pm 21.1 \times 10^{3} \mathrm{~L} / \mathrm{yr}$ (i.e., $316 \pm 15$ $\mathrm{L} /$ ewe), and were attended by $2.3 \pm 0.2$ annual working units (family, $72 \%$ ). Total annual income was €194.4 \pm $23.0 \times 10^{3} / \mathrm{yr}(€ 1.0=\$ 1.3)$ from milk $(78.6 \%)$, lamb $(13.2 \%)$, culled ewes $(0.5 \%)$, and other sales $(0.8 \%$, wool and manure), and completed with the European Union sheep subsidy (6.9\%). Total costs were $€ 185.9 \pm 19.0$ $\times 10^{3} / \mathrm{yr}$ to attend to feeding $(61.6 \%)$, labor $(18.2 \%)$, equipment maintenance and depreciation (7.6\%), finances $(3.0 \%)$, animal health $(2.5 \%)$, energy, water and milking supplies (2.2\%), milk recording (0.5\%), and other costs (4.4\%; assurances, shearing, association fees, and so on). Mean dairy sheep farm profit was $€ 8.5$ $\pm 5.8 \times 10^{3} / \mathrm{yr}(€ 7.4 \pm 8.3 /$ ewe $)$ on average, and varied between -€40.6 and €81.1/ewe among farms. Only $60 \%$ of farms were able to pay all costs, the rest had negative balances. Nevertheless, net margin was €31.0 $\pm 6.5 \times$ $10^{3} / \mathrm{yr}$ on average, varying between $€ 0.6$ and $€ 108.4 \times$ $10^{3} / \mathrm{yr}$ among farms. In this case, without including the opportunity costs, all farms had positive balances. Total annual cost (TAC; $€ /$ ewe) and total annual income (TAI; €/ewe) depended on milk yield (MY; L/ewe) and were $\mathrm{TAC}=161.6+0.502 \mathrm{MY}\left(\mathrm{R}^{2}=0.50\right)$, and TAI $=78.13+0.790 \mathrm{MY}\left(\mathrm{R}^{2}=0.88\right)$, respectively, with the break-even point being $291 \mathrm{~L} /$ ewe. Conversely, farm TAC $(€ / y r)$ and farm TAI $(€ / y r)$ were also predicted as a function of the number of ewes (NOE) per flock, as $\mathrm{TAC}=18,401+282.8 \mathrm{NOE}\left(\mathrm{R}^{2}=0.89\right)$ and TAI $=330.9 \mathrm{NOE}\left(\mathrm{R}^{2}=0.98\right)$, with the break-even point being 383 ewes/flock. Finally, according to the increasing trend expected for agricultural commodity prices, it was calculated that a $10 \%$ increase of concentrate price

Received December 30, 2013.

Accepted March 26, 2014.

${ }^{1}$ Corresponding author: gerardo.caja@uab.es will require $5.2 \%$ milk price increase for constant profit. Similarly, a $10 \%$ increase of forage price will require $2.0 \%$ milk price increase to maintain profitability. Under these scenarios of increasing the commodity prices of key feedstuffs, a change of flock feeding should be expected to compensate the losses in farm profitability. Most Assaf dairy sheep farms studied were economically profitable, with flock size, milk yield, and feeding costs key for their profitability.

Key words: dairy sheep, farm income, expense, economic profit

\section{INTRODUCTION}

Dairy sheep production is a strategic farming option in the Mediterranean basin (45\% of world ewe milk production; FAOSTAT, 2013), where climate (i.e., rain) limits many agricultural activities and a long tradition of consuming sheep dairy products exists (e.g., cheese and yogurt). Spain, with nearly 2.7 million dairy sheep (16\% total sheep population) and $504 \mathrm{ML}$ of ewe milk in 2011 (MAGRAMA, 2013) as a result of an intensification of the dairy sheep industry during the last decade, is ranked fourth in the world for ewe milk production (after Turkey, Greece, and Rumania). Almost 45\% of the Spanish dairy industry is located in the northwest of Spain, in the Community of Castilla y León, which produces $70 \%$ of the total ewe milk production of Spain (MAGRAMA, 2013).

Spanish Assaf, a synthetic crossbreed (5/8 Awassi $\times$ $3 / 8$ east Friesian) originally from Israel and absorbed into Manchega and Castellana local dairy breeds, and occasionally with Churra breed (Legaz et al., 2008), is currently the most important dairy sheep breed in Spain. Total Spanish Assaf population is almost 900,000 sheep, which are mainly located in the autonomous community of Castilla y León, where they are raised under intensive or semi-intensive production systems (Milán et al., 2011; Riveiro et al., 2013). Around 95\% of the Castilla y León sheep milk is processed for highquality cheeses in specialized dairy factories, and nearly $70 \%$ is exported from the area of production (Ugarte et al., 2001).

Despite profuse international spreading of the breed and studies on genetic traits, performance (i.e., milk 
quality, reproduction), and production systems during recent years, a lack of information on the costs and profitability of Spanish Assaf dairy sheep farms under typical intensive conditions is available. Taking into account the dramatic changes that have occurred during recent years in agricultural prices and their effect on farm profitability, a real need exists for economic studies to evaluate the current situation of the farms and their expected trends to allow the farmers and their advisors to manage economical risks and make the right management decisions. With this in mind, the aims of the current study on Spanish Assaf dairy sheep farms were (1) to evaluate the economic structure of incomes and costs, (2) to assess their economic profit, (3) to analyze the effect of feeding costs in the profitability of the farms, and (4) to determine the main break-even points for farm profitability.

\section{MATERIALS AND METHODS}

\section{Area of Study}

We studied a group of Assaf dairy sheep farms located in the northwest of Spain in the autonomous community of Castilla y León. The area has an average altitude of $830 \mathrm{~m}$ above sea level (500 to 2,500 m), low population density $\left(27\right.$ inhabitants $\left./ \mathrm{km}^{2}\right)$, and a Mediterranean climate under continental influence, with dry and hot summers and cold winters. Average rainfall ranges between 300 and $500 \mathrm{~mm}$, peaking in spring and autumn.

\section{Data Collection}

The information was obtained by face-to-face interviews carried out in 2009 with 20 dairy sheep farm stakeholders allocated in the provinces of Zamora (n $=10)$, León $(\mathrm{n}=4)$, Palencia $(\mathrm{n}=3)$, and Valladolid $(\mathrm{n}=3)$. The sample was chosen among commercial farms of Assaf dairy sheep receiving technical advice on feeding and economical management [Gestión Empresarial de Ovino (GEO), Benavente, Zamora, Spain] during the last 5 yr (Milán et al., 2011). Sampled farms were elected according to the availability and reliability of the managerial data (i.e., representing the modern specialized dairy sheep farms under intensified production systems and following the common management practices in the area) and to the representativeness of the average milk yield per ewe in the breed. All data collected was validated by individual GEO advisor auditing.

Data collected corresponded to economical and productive performances in 2008, recorded in flock books, milk and lamb invoices, and farm accountancy, and expressed in the European Union common currency with a conversion rate of $€ 1.0=\$ 1.3$ (European Central Bank, 2013). The questionnaire asked for basic information about the holdings and the relative level of production, farm size, equipment and facilities used, feeds bought, all costs for herd maintenance (including all the factors used in the productive process), and prices and quantities of all products sold by farm. Lacking data were interpolated. All these data were used for taking decisions on feeding, technical support, and economical management by the GEO advisors.

\section{Economic Indicators}

Income. Total annual incomes (TAI) were calculated as the sum of sales (i.e., milk, lambs, breeding and culling livestock, wool, and manure) and subsidies (i.e., European Union sheep subsidies, milk recording) obtained from the ovine activity.

Cost. Total annual costs (TAC) were expressed as the sum of the fixed costs and the variable costs related to milk production. For fixed costs we included the family labor wages (considered as a minimum opportunity cost quantified in $€ 12,000 /$ employee per year), hired labor wages, Social Security fees and insurances, depreciation of buildings, installations, and equipment (estimated by the linear amortization method, with residual value $=0$ and economic lifetime $=25$ yr for buildings and 12 yr for facilities and auxiliary equipment), maintenance and disinfection costs, feeding for maintenance of breeding stock and replacement stock, grazing land fees, pharmaceutical and veterinary services for replacement stock, financial costs of debt and own capital (considered as opportunity cost with an interest rate of 3\%), and other costs (assurances, shearing, association fees, and so on). Buildings, installations, and equipment were valued at their mean value [(acquisition price + residual value)/2] and sheep were valued at current market price (€130/ewe). Depreciation of the flock was not taken into account, and this cost was considered to be equivalent to the total cost of the replacement.

In the variable costs we included the feed resources over maintenance supplied during pregnancy and lactation periods, insemination and lambing, milk recording and milking machine supplies, water, and energy (i.e., carburant and electricity). Costs of feeds produced on the farm (concentrates and forages) were valued at their market price to obtain the isolated actual milk profit (i.e., not including added values of forage and concentrate production) and to correct for the differences between farms in the own fodder production according to their cultivated farm surface. Regression equations for predicting TAI and TAC per ewe, and 
total values in the farm, were calculated from milk yield (MY) and flock size [number of ewes (NOE) per flock], respectively.

Farm Profitability. Different expressions were used to evaluate farm profitability, including the following $(€ / \mathrm{yr})$ :

$$
\begin{gathered}
\text { Farm profit }(\mathbf{F P})=\text { TAI }- \text { TAC; } \\
\text { Net margin }(\mathbf{N M})=\text { FP }+ \text { opportunity costs; } \\
\text { Cash flow }=\mathrm{NM}+\text { depreciation costs; and }
\end{gathered}
$$

Economic efficiency rate $(\mathbf{E E R})=$ TAI $/$ TAC.

Opportunity costs were calculated as the interest of the owned capital (including sheep value) and the remuneration of family labor. Depreciation was calculated as indicated.

Economical return to family labor [RFL; €/annual work unit (AWU) and year] and return to the owned capital (ROC; \%) were calculated for a nonprofit situation as

$$
\begin{gathered}
\mathrm{RFL}=[\mathrm{TAI}-(\mathrm{TAC}-\text { opportunity cost } \\
\text { of family labor })] / \text { familiar AWU, and } \\
\mathrm{ROC}=\{[\mathrm{TAI}-(\mathrm{TAC}-\text { opportunity cost of the } \\
\text { owned capital })] / \text { owned capital }\} \times 100 .
\end{gathered}
$$

The effect of European Union subsidies on farm profitability was evaluated by deleting the amount of subsidy in the total income and calculating FP without subsidies and EER without subsidies.

\section{Statistical and Sensitivity Analyses}

Descriptive and specific statistics were calculated for the farms by using SPSS software (version15, SPSS Inc., Chicago, IL). Pearson correlations were also calculated. Milk yield and flock size break-even points were calculated for $\mathrm{FP}=0$. Break-even for milk yield per ewe was calculated equalizing the TAI and TAC regressions (both expressed as €/ewe and year), assuming that flock size and the rest of the factors and prices were constant. Break-even for flock size was calculated equalizing the TAI and TAC regressions (both expressed as $€ /$ yr), assuming, for this case, that milk yield per ewe and the rest of factors and prices were constant.

Unit costs of milk production $(€ / L)$, the cost directly associated with milk production divided by the number of units, was calculated for each farm by subtracting from TAC the incomes of by-products (lambs, breeding and culling livestock, wool, and manure) and dividing the result by farm milk yield, as indicated by Gharbi et al. (2007) and Idda et al. (2010).

\section{Feeding Costs}

The effect of feeding costs on the profitability of the sheep dairy farms and its relationship with milk price was studied in the case of a typical farm build up from the averaged data of the farm sample used. In this regard, TAI of the farm was expressed by adding the nonmilk income (NMI) and the milk income, which were obtained from MY (L/ewe and year) and milk price $\left(\mathbf{P}_{\mathbf{m}}\right)$, according to the expression

$$
\mathrm{TAI}=\mathrm{NMI}+\mathrm{MY} \times \mathrm{P}_{\mathrm{m}} .
$$

Similarly, TAC was calculated by adding the nonfeeding costs (NFC) and the feeding costs; the latter depending on the amount of feedstuff used per ewe (c $=$ concentrate pellets $; \mathrm{fm}=$ farm mixture $\mathrm{f}=$ forage) and its individual price $\left(\mathbf{P}_{\mathrm{c}}, \mathbf{P}_{\mathrm{fm}}\right.$, and $\left.\mathbf{P}_{\mathrm{f}}\right)$, respectively:

$$
\mathrm{TAC}=\mathrm{NFC}+\mathrm{c} \times \mathrm{P}_{\mathrm{c}}+\mathrm{fm} \times \mathrm{P}_{\mathrm{fm}}+\mathrm{f} \times \mathrm{P}_{\mathrm{f}} .
$$

Finally, from the 2 previous equations, the critical break-even milk price was obtained by

$$
\begin{aligned}
\mathrm{P}_{\mathrm{m}} & =(\mathrm{NFC}-\mathrm{NMI}) / \mathrm{MY}+(\mathrm{c} / \mathrm{MY}) \times \mathrm{P}_{\mathrm{c}} \\
& +(\mathrm{fm} / \mathrm{MY}) \times \mathrm{P}_{\mathrm{fm}}+(\mathrm{f} / \mathrm{MY}) \times \mathrm{P}_{\mathrm{f}} .
\end{aligned}
$$

\section{RESULTS AND DISCUSSION}

\section{Structural Characteristics of Dairy Sheep Farms}

Structural characteristics and performances of the farms studied are summarized in Table 1. It should be stressed that the characteristics of the dairy sheep farm sample used in our study, which were of familiar type, medium to large sized, and fully devoted to milk production, conditioned the generalization of the results to the whole Assaf population. Nevertheless, it should be noted that, for the Spanish and most Mediterranean dairy sector, this is the farm type to which the Assaf dairy farms are tending in a next future. Annual MY in the farm sample considered was approximately $26 \%$ greater than the Assaf-Awassi dairy sheep farms previously studied by Milán et al. $\left(2011 ; 147.0 \times 10^{3}\right.$ L), which was a consequence of the unavailability of a standardized accounting system in the small dairy farms. This result agrees with the growing trend re- 
Table 1. Structural characteristics and performances of the studied Spanish Assaf dairy sheep farms in Castilla y León (Spain)

\begin{tabular}{lcc}
\hline Item & Mean $\pm \mathrm{SE}$ & Interval \\
\hline Total surface, ha & $89.2 \pm 38.0$ & 0 to 745.0 \\
Owned surface, $\%$ & $37.7 \pm 9.3$ & 0 to 100 \\
Sheep, $\mathrm{n}$ & $592 \pm 63$ & 283 to 1,479 \\
Total capital, $€\left(\times 10^{3}\right)^{1}$ & $282.88 \pm 28.22$ & 158.57 to 540.27 \\
Owned capital, \% & $80.1 \pm 5.6$ & 41.9 to 100 \\
Capital invested, $€ /$ ewe & $490.2 \pm 21.4$ & 310.0 to 659.7 \\
Labor & $2.32 \pm 0.21$ & 1.00 to 4.25 \\
$\quad$ Total, AWU & \\
Family, $\%$ & $71.6 \pm 7.1$ & 0 to 100 \\
Ewes/AWU & $261.6 \pm 15.6$ & 151.4 to 389.0 \\
Annual milk yield & & \\
L $\left(\times 10^{3}\right)$ & $185.9 \pm 21.1$ & 76.1 to 450.0 \\
L/ewe & $316.0 \pm 15.2$ & 191.9 to 413.8 \\
\hline
\end{tabular}

${ }^{1}$ Conversion rate $€ 1=\$ 1.3$ (European Central Bank, 2013).

${ }^{2}$ Annual work unit.

ported by Rodríguez et al. (2003) in the average annual MY produced by Castilla y León sheep dairy farms during the period from 1998 to 2002 (63.0 to $112.8 \times$ $10^{3} \mathrm{~L}$ ). Milk yield produced annually in the farms of our study was markedly greater than the values calculated from references in other breeds of dairy sheep, which ranged between 20.9 and $144.0 \times 10^{3} \mathrm{~L}$ (Thomas, 2004; Legarra et al., 2007; Gelasakis et al., 2012), and even exceeded the value reported by Morin and Charroin (2009) for specialized large dairy sheep farms in Roquefort (France; $169.5 \times 10^{3} \mathrm{~L}$ ).

Flock size in the farm sample was also greater than those reported in previous studies done in the same area for primarily Assaf (Mantecón et al., 2009; 521 ewes) and Assaf-Awassi (Milán et al., 2011; 493 ewes) dairy sheep farms, and agreed with the farm size trend reported by Rodríguez et al. (2002) in Castilla y León. Conversely, flock size in our study was smaller than reported in a recent study limited to the province of León (Riveiro et al., 2013; 647 ewes). Nevertheless, no difference in the unitary MY was observed, as the value reported by Milán et al. (2011; 309 L/ewe) was similar to that observed in our data (Table 1). No MY data are available in the Riveiro et al. (2013) study. Values were greater than the mean flock size and MY reported for dairy sheep farms in other areas, as indicated by Morin and Charroin (2009) in Roquefort (France; 372 ewes and $233 \mathrm{~L} /$ ewe), Thomas (2004) in the United States and Canada (145 ewes and $178 \mathrm{~L} /$ ewe), Legarra et al. (2007) in the Basque Country (Spain; 407 ewes and $94 \mathrm{~L} /$ ewe), and Gelasakis et al. (2012) in Macedonia and Thessaly (Greece; 210 ewes and $277 \mathrm{~L} /$ ewe). Nevertheless, Legarra et al. (2007) reported a larger flock size but lower MY in dairy ewes submitted to a milk recording scheme in La Mancha (Spain; 995 ewes and $145 \mathrm{~L} /$ ewe).
Farm surface was markedly greater than reported in the previous studies in Castilla y León (Mantecón et al., 2009; Milán et al., 2011). However, nearly $25 \%$ of our studied farms were landless, similar to Milán et al. (2011) and greater than Mantecón et al. (2009), which conditioned their external dependence for feed purchase. When no-land farms were excluded, mean agricultural area was $72.6 \pm 34.6 \mathrm{ha}$, on average (data not included), with the surface being mainly devoted to fodder production (natural prairies, $40.5 \pm 29.2$ ha; grasses and legumes, $24.7 \pm 7.8 \mathrm{ha}$; cereals for grain, $7.3 \pm 3.3 \mathrm{ha}$ ). Values reported by Milán et al. (2011) showed lower grazing and greater cereal surfaces (including cereals for sale), indicating a greater focus on sheep feeding in our case. Most farm labor was performed by the family (Table 1). Mean labor productivity, expressed as ewes per AWU, fell into the wide range of values reported for dairy sheep farms in the Mediterranean area (88 to 334 ewes/AWU; Morin et al., 2004; de Rancourt et al., 2006; Intxaurrandieta Salaberria et al., 2012).

With regard to farm resources, the studied farms have modern facilities and were equipped in all cases with modern machine milking parlors, according to their dairy specialization, as previously indicated by Milán et al. (2011). Mean total fixed capital (corresponding to buildings, machinery, and equipment, excluding land) in our farm sample was $72.8 \%$, the remaining $27.2 \%$ corresponding to breeding stock. On average, total invested capital of the studied dairy sheep farms (Table 1) fell in the range of values reported by Riveiro et al. (2013; 405 to $908 €$ /ewe) in the province of León during 2010 and according to their farm typology.

\section{Economic Results of the Dairy Sheep Farms}

Income. On average, the studied dairy sheep farms, consequent to their size, showed great values of TAI (Table 2), similar to that reported in France for specialized farms outside the traditional dairy sheep production areas (Morin et al., 2004). Their values were greater than reported previously for conventional dairy sheep farms of Castilla y León (Rodríguez et al., 2003; Mantecón et al., 2006) and organic dairy sheep farms in Castilla-La Mancha (Toro-Mujica et al., 2012). Ewe milk price in Spain steadied throughout the period from 2000 to 2011 (MAGRAMA, 2013), making possible a direct comparison of farm incomes across the Spanish references. Conversely, Morin and Charroin (2009) reported much greater incomes $(163 \%)$ for the specialized large dairy sheep farms in Roquefort $\left(€ 317.2 \times 10^{3}\right)$, despite their lower annual MY, as a consequence of the higher price of the ewe milk and the amount of farm subsidies in France when compared with Spain for the same period. 
Table 2. Annual incomes of Assaf dairy sheep farms in Castilla y León (Spain)

\begin{tabular}{lccc}
\hline Item & Mean $\pm \mathrm{SE}$ & Interval & $\%$ \\
\hline Total incomes, $€ /$ yr $^{1}$ & $194,449 \pm 23,005$ & 84,719 to 509,483 & \\
Milk, $€ /$ ewe and year & $257.33 \pm 12.10$ & 157.57 to 343.45 & 78.6 \\
Lamb sales, $€ /$ ewe and year & $43.29 \pm 3.70$ & 16.82 to 81.59 & 13.2 \\
Culled ewes, $€$ /ewe and year & $1.60 \pm 0.23$ & 0.18 to 4.75 & 0.5 \\
Other, $^{2} € /$ ewe and year & $2.63 \pm 1.05$ & 0.34 to 19.58 & 0.8 \\
Subsidies, $€ /$ ewe and year & $22.74 \pm 1.02$ & 13.10 to 33.99 & 6.9 \\
Total, $€ /$ ewe and year & $327.58 \pm 12.78$ & 229.45 to 426.04 & 100 \\
\hline
\end{tabular}

${ }^{1}$ Conversion rate $€ 1=\$ 1.3$ (European Central Bank, 2013).

${ }^{2}$ Wool, manure, breeding stock, and so on.

With regard to the annual milk incomes per ewe, our results (Table 2) were in the range of those reported by Mantecón et al. (2006; €248/ewe) and De la Fuente et al. (2006; €282/ewe) in Assaf dairy sheep farms under intensive conditions in Castilla y León (Spain). Morin and Charroin (2009) reported large differences between specialized dairy sheep farms according to location, with the range of values for Roquefort ( $€ 318$ to $€ 333$ / ewe) similar to that obtained in the upper range of our study, but greater than reported for the Atlantic Pyrenees ( $€ 157$ to $€ 189 /$ ewe).

Milk sales were the main income component (Table 2) in all farms in our study, mean value being similar to that reported by Mantecón et al. (2006; 79\%), but much higher than reported by De la Fuente et al. (2006; 63\%). Moreover, milk incomes were greater than reported for other Spanish local dairy sheep breeds (Rodríguez et al., 2002; 67\%; De la Fuente et al., 2006; 38\%), organic dairy sheep farms in La Mancha (Toro-Mujica et al., $2012 ; 54 \%$ ), and even greater than obtained in typical family dairy sheep farms in the Valley of Belice (Italy), although in this case without European Union subsidies (Tolone et al., 2011; 72\%).

Similar to that reported for milk price, lamb price in Spain was approximately constant during the period from 2000 to 2011 (MAGRAMA, 2013), making a direct comparison of lamb sale incomes between references possible. Therefore, total incomes from lamb sales per ewe were slightly lower than reported by De la Fuente et al. (2006; €48/ewe and year), but greater than Mantecón et al. (2006; €37/ewe and year) for the group of intensive Assaf dairy farms. However, lamb sale income per ewe were much lower than those reported for a similar lamb weight ("lechal," light milk-fed lamb $<10$ $\mathrm{kg}$ of BW) from Spanish local breeds under European Union Geographical Protected Indication meat labels (De la Fuente et al., 2006; €56/ewe and year), which are highly demanded and appreciated by consumers. Consequently, the percentage of income from lamb sales was lower than previously discussed for milk, supporting the dairy specialization of the studied farms (Table 2).
Conversely, incomes from the direct subsidies paid by the European Union to sheep farms, according to the current common agricultural policy, were $€ 13,276$ / farm and year, on average, reaching a value close to the cost of an AWU in this area. This subsidy was approximately $7 \%$ of TAI in the studied farms, which was lower than reported for similar dairy sheep farms in the area (9 to $21 \%$ depending on sheep breed and production system) according to Mantecón et al. (2006) and De la Fuente et al. (2006). Moreover, direct subsidies percentage was also lower than reported in other Spanish dairy sheep farms in the Basque Country (Ruiz et al., 2002; 17 to 20\%) and organic farms in Castilla-La Mancha (Toro-Mujica et al., 2011; 14\%). Similarly, our value was lower than reported by Morin and Charroin (2009) for French dairy sheep farms in specialized dairy sheep farms in Roquefort (14-21\%) and in the Atlantic Pyrenees (19-26\%). In this sense, according to de Rancourt et al. (2006), it can be calculated that values of direct subsidies for sheep farms contributed 20 (Greece), 21 (Spain), 22 (Italy), and 38\% (France) to TAI. These results support the general statement that dairy sheep farms were less dependent on subsidies than meat sheep farms, and intensive farms were less dependent than extensive farms. Nevertheless, it should be stressed that, in our study, we only considered those subsidies directly attributable to sheep activity (i.e., breeding stock, traditional activity in less-favored areas), and not those attributable to other farm activities (i.e., culture surfaces), because, in the latter case, prices of fodders indirectly include the values of crop subsidies.

Total annual income per ewe (TAI/ewe, €/ewe and year) was predicted as a function of ewe MY, by the equation $\left(\mathrm{R}^{2}=0.88 ; P<0.001 ;\right.$ Figure 1$)$ :

$$
\begin{gathered}
\text { TAI/ewe }( \pm 20.40)=78.1( \pm 22.3) \\
+0.789( \pm 0.069) \times \mathrm{MY}
\end{gathered}
$$

The obtained equation showed a significant regression coefficient slightly lower than the mean milk price calculated across farms $(0.816 \pm 0.004 € / L)$. Conversely, 


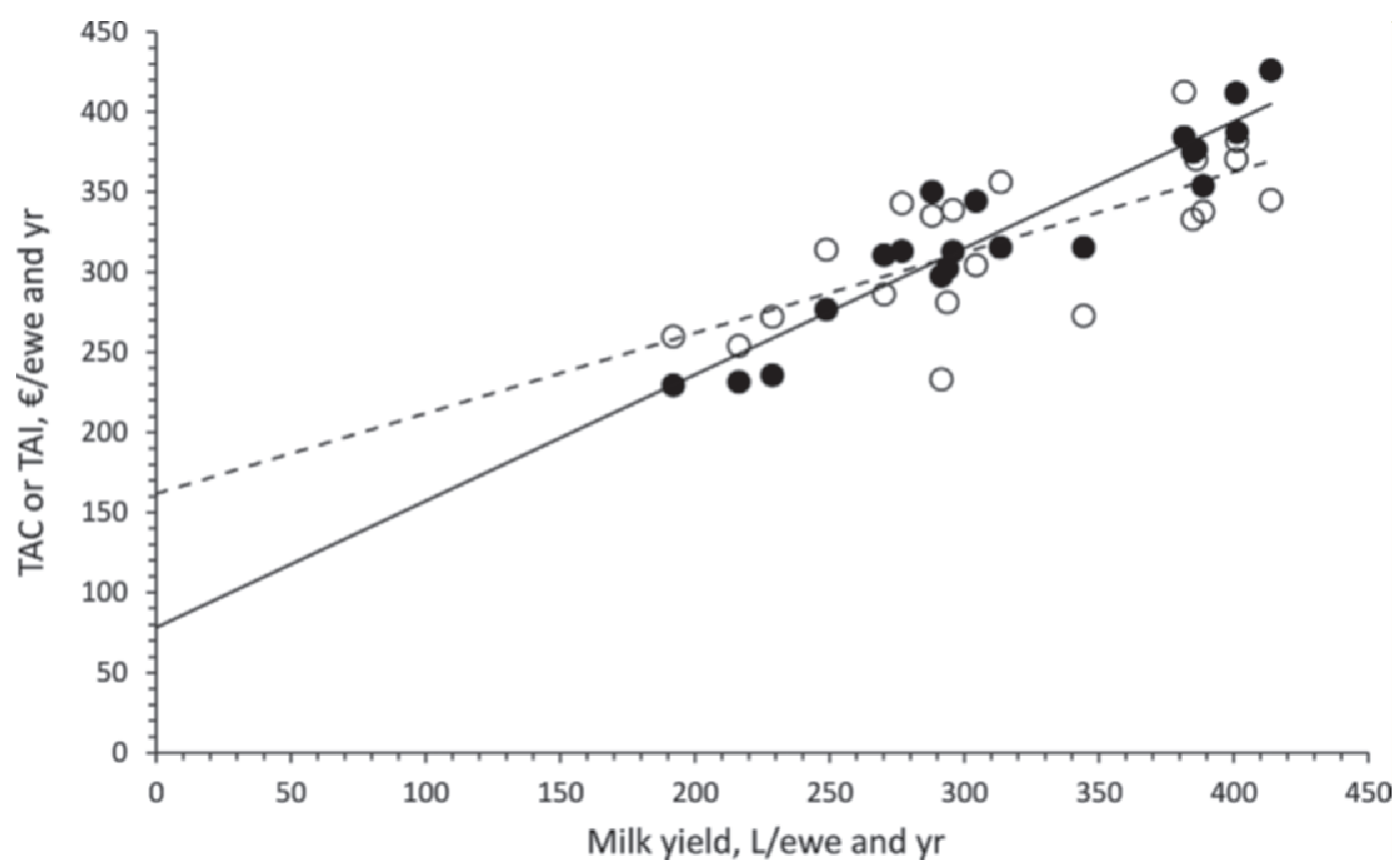

Figure 1. Relationship between ewe milk yield (MY; L/ewe and year), total annual income (TAI; $€$ /ewe and year $=0.5018 \mathrm{MY}+161.6 ; \mathrm{R}^{2}$ $=0.50 ;--)$, and total annual cost $\left(\mathrm{TAC} ; € /\right.$ ewe and year $\left.=0.7894 \mathrm{MY}+78.1 ; \mathrm{R}^{2}=0.88 ;--\bigcirc--\right) ; \mathrm{n}=20$.

farm TAI $(€ /$ yr $)$ was also predicted as a function of NOE by the equation $\left(\mathrm{R}^{2}=0.98 ; P<0.001 ;\right.$ Figure 2$)$ :

$$
\text { TAI }( \pm 33,166)=330.9( \pm 11.3) \times \text { NOE. }
$$

Given the value of the dairy ewes previously considered in the present study, an annual return of approximately 2.6 times the ewe value can be calculated.

Cost. Values of TAC of the studied farms are shown in Table 3. As expected, their magnitude was related to the large size of the farms. Comparison of these results with the previously published data needs to be done carefully because of the differences in assumptions and calculation methodology (i.e., in our study we included the opportunity costs for family labor and own capital, among others).

Total feeding cost (€197.3 \pm 7.1 /ewe, $61.6 \%$; value derived from Table 3) was the greatest component of TAC in the studied dairy sheep farms. With the aim of analyzing this important cost, we split the total feeding cost into 2 components (Table 3 ) (1) a fixed component per ewe (i.e., feeding for maintenance of breeding stock and feeding for replacement stock) and (2) a variable component proportional to the ewe milk yield (i.e., feeding for milk production). The total amount of feeding costs in our study were greater than those reported by Mantecón et al. (2006; €145/ewe and 68\%) and De la Fuente et al. (2006; €123/ewe and 57\%) using the same breed and similar exploitation conditions in Castilla y
León. Our feeding costs represented a greater value, but a similar percentage, of that reported by Sánchez et al. (2004; €160/ewe and 62\%) using a similar methodology in intensive dairy sheep in Los Pedroches (Córdoba, Spain). Conversely, it should be noted that important changes were observed in the price of commodities according to the date of the study. Moreover, as previously indicated, Spanish feeding costs were greater than those reported in dairy sheep in Greece (Tzouramani et al., 2011; €90.3/ewe and 48\%) and Sicily (Tolone et al., 2011; €128.2/ewe).

Annual labor cost (18.2\%; Table 3$)$ was the second main component in our studied farms. It corresponded to the valuation of family labor (€33.9 \pm 3.6 /ewe; $58 \%$ ), wages paid to employees (€14.0 \pm 4.0 /ewe; $24 \%$ ), and social security taxes $(€ 10.5 \pm 0.7 /$ ewe; $18 \%$ ). Quantification of family labor is imprecise and difficult to compare because it was estimated as an opportunity cost. Moreover, social security costs are different between countries. In any case, the values of our study (Table 3) were higher than those reported by ToroMujica et al. (2012) in organic dairy sheep farms in La Mancha (€48.6/sheep) and Tzouramani et al. (2011) in conventional and organic dairy sheep farms in Greece (€37.1 and €39.8/sheep, respectively).

Depreciation annual cost in our data (Table 3) was greater than the value $€ 7.2$ /ewe reported by Rodríguez et al. (2002) in the same area and breed, although the difference can be explained by the high investments 
Table 3. Annual costs of Assaf dairy sheep farms in Castilla y León (Spain)

\begin{tabular}{|c|c|c|}
\hline Item & Mean $\pm \mathrm{SE}^{1}$ & Interval \\
\hline Total costs, $€ / \mathrm{yr}^{1}$ & $185,908 \pm 19,033$ & 94,221 to 450,423 \\
\hline \multicolumn{3}{|l|}{ Fixed costs, $€ /$ ewe and year } \\
\hline Depreciation, maintenance and repairs & $24.33 \pm 2.43$ & 7.56 to 46.98 \\
\hline Financial $^{2}$ & $9.80 \pm 0.74$ & 4.02 to 15.59 \\
\hline \multicolumn{3}{|l|}{ Feeding } \\
\hline Flock maintenance & $51.35 \pm 3.21$ & 14.22 to 71.92 \\
\hline Replacement stock & $18.54 \pm 1.10$ & 11.65 to 30.57 \\
\hline Health of replacement stock & $2.15 \pm 0.37$ & 0.36 to 6.25 \\
\hline Labor $^{3}$ & $58.34 \pm 3.98$ & 30.07 to 94.20 \\
\hline Other $^{4}$ & $13.96 \pm 0.83$ & 9.07 to 22.86 \\
\hline Total fixed & $178.47 \pm 7.57$ & 107.45 to 230.68 \\
\hline \multicolumn{3}{|l|}{ Variable costs, $€ /$ ewe and year } \\
\hline Feeding of breeding stock ${ }^{5}$ & $127.36 \pm 6.97$ & 78.10 to 196.15 \\
\hline Divers $^{6}$ & $6.99 \pm 0.56$ & 2.69 to 12.86 \\
\hline Health of breeding stock & $5.75 \pm 0.56$ & 2.31 to 10.05 \\
\hline Milk recording & $1.62 \pm 0.33$ & 0 to 5.05 \\
\hline Total variable & $141.72 \pm 7.06$ & 94.71 to 204.70 \\
\hline Total annual cost, $€$ /ewe and year & $320.19 \pm 10.75$ & 233.28 to 412.69 \\
\hline
\end{tabular}

${ }^{1}$ Conversion rate $€ 1=\$ 1.3$ (European Central Bank, 2013).

${ }^{2}$ Interest of debt and opportunity costs of own capital breeding stock investment (3\%).

${ }^{3}$ Employee labor and social security and opportunity cost of family labor.

${ }^{4}$ Assurances, shearing, association fees, transportation, and so on.

${ }^{5}$ Pregnant and lactating ewes.

${ }^{6}$ Energy, water, and milking supplies.

that were done in the studied farms during the last decade (Milán et al., 2011; Riveiro et al., 2013). Our data was lower than reported by Tzouramani et al. (2011) in conventional and organic dairy sheep farms in Greece (€37.2 and €27.4/ewe, respectively), including, in this case, the capital interest. The high values of total capi- tal invested (Table 1) and the depreciation cost (Table 3) were indicative of a capital-intensive activity.

Total annual cost per ewe $(€ /$ ewe and year) was predicted as a function of ewe MY (L/ewe and year), as shown in Figure 1, by the equation $\left(\mathrm{R}^{2}=0.50 ; P<\right.$ $0.001)$

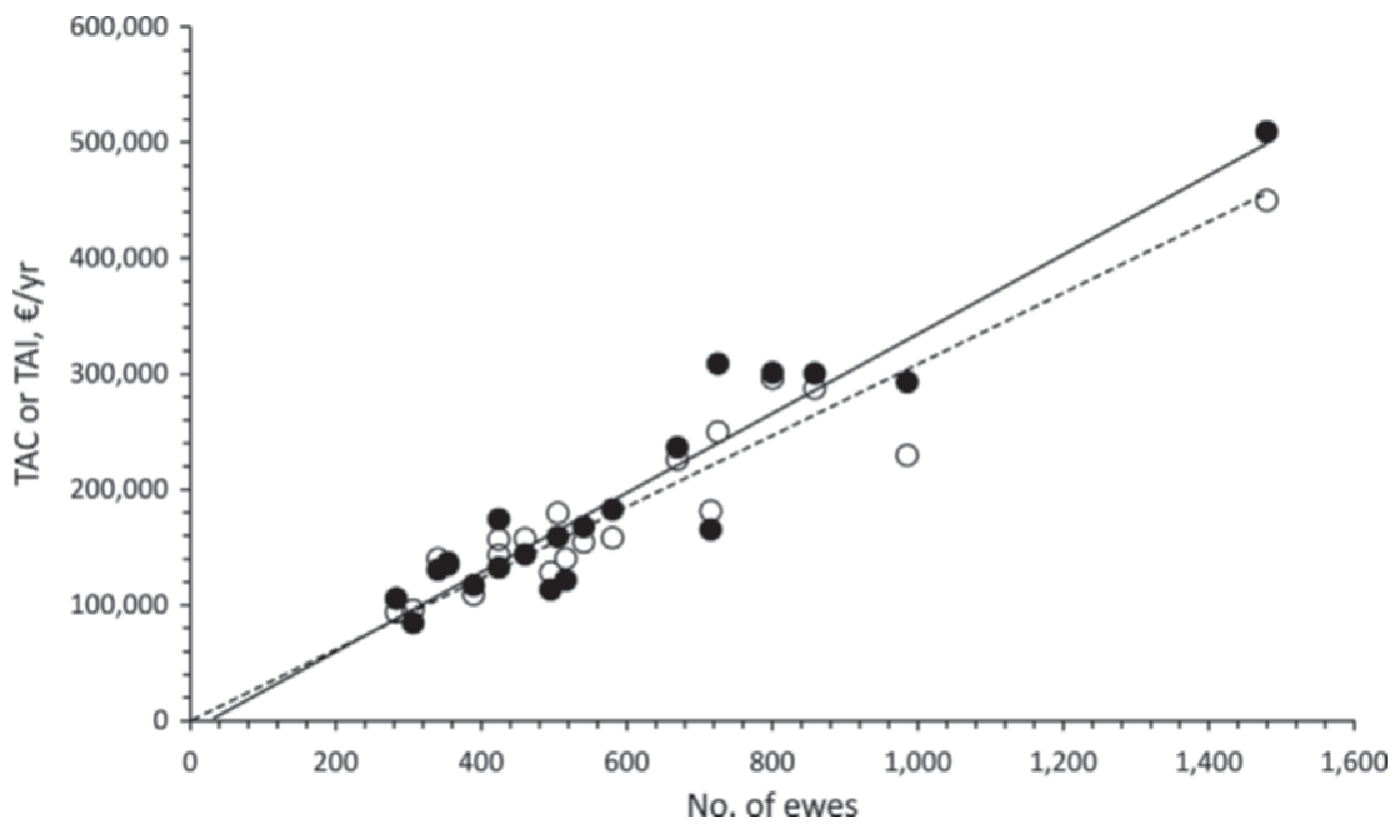

Figure 2. Relationship between flock size (number of ewes; NOE), total annual income (TAI, €/yr; TAI $=330.9$ NOE; $\mathrm{R}^{2}=0.98 ;-\bullet-$ ), and total annual costs (TAC, $€ / \mathrm{yr} ; \mathrm{TAC}=282.8 \mathrm{NOE}+18,401 ; \mathrm{R}^{2}=0.89 ;--\mathrm{O}--$ ); $\mathrm{n}=20$. 
MILÁN ET AL.

Table 4. Economic results of Assaf dairy sheep farms in Castilla y León (Spain)

\begin{tabular}{lcc}
\hline Item & Mean $\pm \mathrm{SE}$ & Interval \\
\hline Net margin, ${ }^{1} € / \mathrm{yr}$ & $31,010 \pm 6,490$ & 639 to 108,378 \\
Net margin without subsidies, $€ / \mathrm{yr}$ & $17,734 \pm 5,580$ & $-10,160$ to 72,377 \\
Farm profit, $€ /$ yr & $8,541 \pm 5,828$ & $-20,514$ to 63,390 \\
Farm profit without subsidies, $€ / \mathrm{yr}$ & $-4,736 \pm 5,204$ & $-32,917$ to 49,258 \\
Cash flow, $€ /$ yr & $43,421 \pm 7,465$ & 6,783 to 137,136 \\
Economic efficiency coefficient $(\mathrm{EER})$ & $1.03 \pm 0.03$ & 0.87 to 1.28 \\
EER without opportunity costs & $1.18 \pm 0.03$ & 1.01 to 1.44 \\
EER without subsidies & $0.95 \pm 0.03$ & 0.77 to 1.20 \\
Return to family labor, $€$ /annual work units per year & $19,147 \pm 4,840$ & 3,099 to 75,390 \\
Return to own capital, $\%$ & $3.58 \pm 2.33$ & -13.46 to 21.46 \\
\hline
\end{tabular}

${ }^{1}$ Conversion rate $€ 1=\$ 1.3$ (European Central Bank, 2013).

$$
\begin{gathered}
\text { TAC/ewe }( \pm 34.8)=161.6( \pm 38.0) \\
+0.502( \pm 0.118) \times \mathrm{MY}
\end{gathered}
$$

Despite the low regression coefficient obtained, this equation shows the marginal cost of increasing MY, which was $€ 0.502 \pm 0.118 / \mathrm{L}$ on average for the mean farm in the sample studied. Moreover, the intercept of the equation was lower than the fixed costs value, shown in Table 3, the difference (-€16.9 or 9.5\%) being a consequence of attributing the character of fix cost to some of the variable costs (depending on MY).

Moreover, farm total annual costs (TAC, €/yr) was calculated as a function of flock size, as shown in Figure 2 , by the equation $\left(\mathrm{R}^{2}=0.89 ; P<0.001\right)$

$$
\begin{gathered}
\text { TAC }( \pm 29,029)=18,401( \pm 15,334) \\
+282.8( \pm 23.4) \times \text { NOE } .
\end{gathered}
$$

In this case the estimated regression coefficient indicated the costs directly dependent on NOE (feeding cost, milk recording, opportunity costs of breeding stock, and other costs) for MY being constant. Comparison of the coefficient value with the results shown in Table 3 is not possible because, in this case, cost partitioning was done considering NOE constant and MY variable.

Farm Profitability. A large variability in FP values was observed in the studied farms (Table 4). This was mainly a consequence of the large differences in NOE and MY between farms (Table 1), as well as in individual business management differences. On average, the studied farms obtained a relatively low annual FP $(1.2 \%$ TAI; range of variation $=-15.5$ to $21.6 \%$ TAI $)$, when all incomes and costs were quantified, including the opportunity costs. Only $60 \%$ of farms were able to reward all the necessary components to carry out the production process, the rest having negative results. Nevertheless, when European Union subsidies were removed, value of $\mathrm{FP}$ without subsidies was on average negative (Table 4), indicating a high dependence on these subsidies. In this case, only $30 \%$ farms showed positive FP without subsidy values.

Profitability evaluation changed considerably when NM was calculated (Table 4), being on average $14.4 \%$ TAI (range of variation $=0.6$ to $30.4 \%$ TAI), with all the farms studied obtaining a positive result in this case. Our mean NM value per farm (Table 4) was $18 \%$ lower than reported for dairy sheep farms of Castilla y León during the period 1998 to 2002 (Rodríguez et al., $2003 ; € 37,656$ ).

Cash flow, as an indicator of available revenue and liquidity of farms, was positive in all the studied farms (Table 4), allowing the farms to face the usual flow of payments. With regard to EER (Table 4), obtained values indicated that, on average, farm incomes exceed $3 \%$ of total costs and $18 \%$ when the opportunity costs were not taken into account. On the contrary, when European Union subsidies were eliminated in the calculations, a $5 \%$ deficit was observed on average. It may be expected that, if the subsidies were abolished, the milk market would be modified (i.e., milk supply and demand changes). It should also be noted that, given the low elasticity of milk demand (i.e., traditional market cheeses) as reported by Bouamra-Mechemache et al. (2008), modifications to the milk market would tend to increase milk price at midterm and, consequently, the farm profitability results obtained in the current study.

On average, for the studied farms, return to family labor (Table 4) was higher than the mean salary paid to external workers $(€ 10,185 \pm 740 /$ AWU). Moreover, the return to the owned capital value obtained in the studied dairy sheep farms (Table 4) was, on average, approximately 1.25 points lower than the interest rates paid in Europe during the period of study (Eurostat, $2010 ; 4.83 \%)$.

\section{Sensitivity Analyses and Milk Production Costs}

Estimated break-even point for MY from equations 10 and 12 was $291 \mathrm{~L} /$ ewe and year, which was largely 
Table 5. Production cost of milk in Assaf dairy sheep farms of Castilla y Léon (Spain)

\begin{tabular}{lrr}
\hline Item & Mean $\pm \mathrm{SE}$ & \multicolumn{1}{c}{ Interval } \\
\hline Production cost & $0.806 \pm 0.028$ & 0.559 to 0.980 \\
Production cost without subsidies & $0.882 \pm 0.032$ & 0.633 to 1.107 \\
Production cost without opportunity cost of capital & $0.781 \pm 0.028$ & 0.535 to 0.954 \\
Production cost without opportunity costs & $0.667 \pm 0.021$ & 0.493 to 0.814 \\
Milk price & $0.816 \pm 0.004$ & 0.780 to 0.856 \\
Milk price - production cost & $0.010 \pm 0.027$ & -0.160 to 0.221 \\
Milk price - production cost without subsidies & $-0.067 \pm 0.031$ & -0.287 to 0.164 \\
Milk price - production cost without opportunity cost of capital & $0.035 \pm 0.027$ & -0.143 to 0.245 \\
Milk price - production cost without opportunity costs & $0.149 \pm 0.021$ & 0.007 to 0.287 \\
\hline
\end{tabular}

greater than the value reported for a dairy sheep farm of 300 ewes with winter lambing in the United States (Berger, 2002; $180 \mathrm{~L} /$ ewe). Break-even point for NOE from equations 11 and 13 was 383 ewes/flock, which was also greater than reported for intensive dairy sheep farms in Spain (Sánchez et al., 2004; 294 ewes). Nevertheless, both values fit within the range of variation of the studied dairy sheep farm sample in Castilla y León, and far from the mean values reported in Table 1.

Break-even point for sheep milk price, or mean milk production cost reported in Table 5, was slightly lower (approximately -1\%) than the average milk sale price in the farms during the period of study and also reported in Table 5. Moreover, values of milk price margins calculated under different subtracting assumptions (i.e., without subsidies, without own capital opportunity costs, without opportunity costs) are also shown in Table 5.

\section{Feeding Allowances and Sensitivity Analyses of Feeding Costs}

Assaf dairy sheep farms in Castilla y León are characterized by intensive production systems, most of them in permanent stables, indoor feeding of a TMR (based in dry forages and concentrates), and occasionally grazing on stubble and culture residue during the nonlactating period (Milán et al., 2011; Riveiro et al., 2013). Annual feed allowances in the studied dairy sheep farms agreed with this typical feeding system, with the observed mean forage-to-concentrate ratio (as fed) approximately 40:60 (Table 6). Total amount of concentrate was elevated and in the upper range of the values reported by Milán et al. (2011). On average, concentrates cover $70.0 \%$ annual energy allowances of the ewes, the amount of concentrate farm mixture being approximately twice that of the commercial concentrate used.

Values reported in Table 6 agree with the calculated requirements of a standard Assaf ewe at $80 \mathrm{~kg}$ of BW (maintenance $=1.50 \mathrm{Mcal}$ of $\mathrm{NE}_{\mathrm{L}} / \mathrm{d}$ ) and averaging $0.88 \mathrm{~L} / \mathrm{d}$ of milk $(7.0 \%$ fat and $5.5 \%$ protein, $1.63 \mathrm{Mcal}$ of $\mathrm{NE}_{\mathrm{L}} / \mathrm{L}$ ), equivalent to $321 \mathrm{~L} / \mathrm{yr}$, which fits the mean milk yield value per ewe reported in Table 1. Milk price and feeding cost (61.6\% of total costs), as key factors of the incomes and expenses of the studied dairy sheep farms, respectively, were related for assessing their effect on farm profit. Values from Tables 1 and 2 and expression (equation 7) were used to calculate the total incomes and costs of the typical averaged farm (i.e., 592 ewes yielding $316 \mathrm{~L} /$ ewe), by the equation of total income:

$$
\text { TAI }(€ / \text { ewe })=70.25+316.0 \times \mathrm{P}_{\mathrm{m}} \text {. }
$$

Conversely, values from Table 3 and 6 were used to calculate total costs in expression (equation 8) as a function of the feedstuff prices, by

Table 6. Annual allowances of Assaf dairy sheep farms in Castilla y Léon (values are means $\pm \mathrm{SE}$ )

\begin{tabular}{|c|c|c|c|c|}
\hline Ingredient & Offered, $\mathrm{kg} /$ ewe & Price, ${ }^{1} € / \mathrm{kg}$ & $\begin{array}{c}\text { Net energy, }{ }^{2} \\
\text { Mcal of } \mathrm{NE}_{\mathrm{L}} / \mathrm{kg}\end{array}$ & $\begin{array}{l}\text { Offered, Mcal } \\
\text { of } \mathrm{NE}_{\mathrm{L}} / \text { ewe }\end{array}$ \\
\hline Concentrate $^{3}$ & $167.1 \pm 18.4(19.5 \%)$ & $0.330 \pm 0.003$ & 1.70 & $284(26.5 \%)$ \\
\hline Farm mixture ${ }^{4}$ & $343.3 \pm 38.2(40.1 \%)$ & $0.220 \pm 0.003$ & 1.36 & $467(43.5 \%)$ \\
\hline Total & $856.4 \pm 33.5(100 \%)$ & - & 1.29 & $1,073(100 \%)$ \\
\hline
\end{tabular}

\footnotetext{
${ }^{1}$ Conversion rate $€ 1=\$ 1.3$ (European Central Bank, 2013).

${ }^{2}$ Estimated according to INRA (2007) tables; energy content of $1 \mathrm{~kg}$ of barley (as fed) $=1.7 \mathrm{Mcal}$ of $\mathrm{NE}_{\mathrm{L}}$.

${ }^{3}$ Commercial concentrate including minerals and vitamins complex.

${ }^{4}$ Commodity mixtures made in the farm based on barley and oat whole grains, soybean meal, and beet pulp.

${ }^{5}$ Hays, dehydrated forages, and cereal straw; grazing on stubbles and culture residues not included.
} 


$$
\begin{gathered}
\text { TAC }(€ / \text { ewe })=141.48+167.13 \times \mathrm{P}_{\mathrm{c}} \\
+343.31 \times \mathrm{P}_{\mathrm{fm}}+345.69 \times \mathrm{P}_{\mathrm{f}} .
\end{gathered}
$$

Finally, break-even milk price was calculated as a function of feedstuff prices using the expression (equation $9)$, as

$$
\begin{aligned}
\mathrm{P}_{\mathrm{m}}= & 0.225+0.530 \times \mathrm{P}_{\mathrm{c}}+1.087 \\
& \times \mathrm{P}_{\mathrm{fm}}+1.094 \times \mathrm{P}_{\mathrm{f}}
\end{aligned}
$$

Coefficients of this equation show that $0.53 \mathrm{~kg}$ of concentrate pellets $(19.6 \%), 1.09 \mathrm{~kg}$ of farm mixture $(40.2 \%)$, and $1.09 \mathrm{~kg}$ of dry forage $(40.2 \%)$ were necessary for producing $1 \mathrm{~L}$ of milk. According to the market prices reported in Table 6 , it was estimated that $\mathrm{P}_{\mathrm{fm}}=$ $0.66 \times \mathrm{P}_{\mathrm{c}}$, resulting in

$$
\mathrm{P}_{\mathrm{m}}=0.225+1.254 \times \mathrm{P}_{\mathrm{c}}+1.094 \times \mathrm{P}_{\mathrm{f}} .
$$

Similarly, it can be calculated that approximately $1.25 \mathrm{~kg}$ of concentrates (53.4\%) and $1.09 \mathrm{~kg}$ of dry forages $(46.6 \%)$ were necessary per $1 \mathrm{~L}$ of milk. Break-even milk price for the average feed prices reported in Table 6 was $€ 0.798 / L$. In the current market scenario, with an average $\mathrm{P}_{\mathrm{m}}=€ 0.816 / \mathrm{L}$ as obtained in the current study (Table 5), the milk profit for the typical average farm was estimated as $€ 0.018 / \mathrm{L}(2.2 \%)$. The milk profit here obtained for the typical farm was greater than the value reported in Table $5(€ 0.010 / \mathrm{L})$ for the mean of the studied dairy sheep farms.

Break-even prices for concentrates and forages for the typical farm of the current study were $€ 0.34$ and $€ 0.16 /$ $\mathrm{kg}$, respectively, which agreed with the values observed in the Castilla y León local markets (MAGRAMA, 2013). Moreover, it can be calculated that a $10 \%$ increase of the price of concentrate pellets would need a $5.2 \%$ increase in $\mathrm{P}_{\mathrm{m}}$ to maintain dairy sheep farm profit. Similarly, a $10 \%$ increase of the price of forage would need a $2.0 \%$ increase in $\mathrm{P}_{\mathrm{m}}$. Under these scenarios of increasing commodity prices of key feedstuffs, a change of flock-feeding strategies (e.g., optimizing concentrateto-forage ratio, increasing milk yield to reduce the load of maintenance expenditures, modifying milk quality, and so on) should be expected to compensate the losses in farm profitability. Additionally, as previously indicated, as a consequence of the low elasticity of sheep milk demand, an increase in commodity price would increase the milk price at midterm more than reducing the amount of milk demanded by the dairy milk industry. We can estimate that with a $10 \%$ increase of both concentrate and forage prices, a $7.2 \%$ increase in milk price would be needed to maintain the benefit, which translates to an increase in the production cost of the ewe cheese in the dairy industry.

Although no similar data are available on dairy sheep for comparison, Morin and Charrion (2009) used the IPAMPA index (index of market prices of commodities), which covers between 65 and $80 \%$ of costs, for the economical assessment of dairy sheep farms in France. Those authors concluded that dairy sheep farms are as sensitive as dairy cow farms to the variation of feeding costs (2.1 and 2.2\% accumulated annual index, respectively), and more sensitive than meat sheep farms (0.3 times). Conversely, the dairy cattle industry also uses different indicators for assessing milk production profitability, reflecting the difference between the milk price and the cost of the feed required to make that milk (Bailey and Ishler, 2007; Wolf, 2010); no possible comparison with our data exists, however.

\section{CONCLUSIONS}

Studied Spanish Assaf dairy sheep farms were of familiar type, medium to large sized, fully devoted to milk production, and most were economically profitable. Average values of cash flow, economic efficiency rate, and return to family labor and capital investment indicated that they do not have liquidity problems and that they adequately remunerate the production factors. Dependence on European Union agricultural subsidies was lower than in other sheep farm types, but essential for profitability. Flock size, MY, and feeding cost (the greatest milk production cost in dairy ewes) were a key for dairy sheep farm profitability. Break-even points for milk yield and farm size were easily achievable under the current circumstances, but according to the expected increase in feedstuff prices, a proportional increase in feeding efficiency, productivity or milk price would be necessary to maintain their future profitability. Moreover, once the break-even points are achieved, we considered that the main factor of success in farm profitability should be management efficiency rather than farm size or ewe milk yield.

\section{ACKNOWLEDGMENTS}

This work was supported by a research scholarship to F. Frendi from the International Centre for Advanced Mediterranean Agronomic Studies (Instituto Agronómico Mediterráneo de Zaragoza, Zaragoza, Spain). The authors are also grateful to the farmers and technicians of the Group GEO (Gestión Empresarial de Ovino) and to the ASSAF.E (Asociación Española de Criadores de Ganado Ovino de Raza Assaf, Toro, Zamora, Spain) for their support, and to Nic Aldam (Barcelona, Spain) for the English revision of the manuscript. 


\section{REFERENCES}

Bailey, K., and V. Ishler. 2007. Tracking milk prices and feed costs. Pennsylvania State University report. Accessed Nov. 14, 2012. http://extension.psu.edu/animals/dairy/business-management/ financial-tools/income-over-feed-cost/publications/tracking-milkprices-and-feed-costs/view.

Berger, Y. M. 2002. Economics of winter milking for medium to large dairy sheep operations. Pages 118-126 in Proceedings of the 8th Great Lakes Dairy Sheep Symposium. Cornell University, Ithaca, New York. Accessed Apr. 10, 2013. http://www.ansci.wisc.edu/ Extension-New\%20copy/sheep/Publications_and_Proceedings/ symposium $\% 20 \mathrm{PDF} /$ Great $\% 20$ lakes2002\%20symposium.pdf.

Bouamra-Mechemache, Z., V. Réquillart, C. Soregaroli, and A. Trévisiol. 2008. Demand for dairy products in the EU. Food Policy 33:644-656.

De la Fuente, L. F., D. Gabiña, N. Carolino, and E. Ugarte. 2006. The Awassi and Assaf breeds in Spain and Portugal. 57th Annual Meeting of the European Federation of Animal Science (EAAP), Antalya, Turkey. Accessed Dec. 16, 2013. http://www.eaap. org/Previous_Annual_Meetings/2006Antalya/Papers/S14.2_ Delafuente.pdf.

de Rancourt, M., N. Fois, M. P. Lavín, E. Tchakérian, and F. Vallerand. 2006. Mediterranean sheep and goats production: An uncertain future. Small Rumin. Res. 62:167-179.

European Central Bank. 2013. Euro exchange rates: USD. Accessed Jan. 2013. http://www.ecb.int/stats/exchange/eurofxref/html/ eurofxref-graph-usd.en.html.

Eurostat. 2010. Official European Union Statistics. Accessed Apr. 3, 2010. http://epp.eurostat.ec.europa.eu/portal/page/portal/ agriculture/data.

FAOSTAT. 2013. The Statistics Division of the Food and Agriculture Organization of the United Nations. Accessed Dec. 17, 2013. http://faostat.fao.org/site/569/default.aspx\#ancor.

Gelasakis, A. I., G. E. Valergakis, G. Arsenos, and G. Banos. 2012. Description and typology of intensive Chios dairy sheep farms in Greece. J. Dairy Sci. 95:3070-3079.

Gharbi, F. R., R. Lahsoumi, F. Gouhis, and Z. Rached. 2007. Rentabilité économique de l'élevage laitier en Tunisie: Cas des Gouvernorats de l'Ariana et de Mahdia. Biotechnol. Agron. Soc. Environ. 11:211-223.

Idda, L., R. Furesi, and P. Pulina. 2010. Economia dell'Allevamento Ovino da Latte. Produzione, Transformazione, Mercato. Franco Agneli, Milano, Italy.

INRA. 2007. Alimentation des Bovins, Ovins et Caprins. Besoins des Animaux - Valeurs des Aliments. Tables INRA 2007. Editions Quae, Versailles, France.

Intxaurrandieta Salaberria, J. M., J. M. Lasarte, and P. Lazkanotegi Mugica. 2012. Ovino de leche en Navarra: Evolución de la producción y resultados por sistemas productivos. Pequeños Rumiantes $13: 14-19$

Legarra, A., M. Ramón, E. Ugarte, and M. D. Pérez-Guzmán. 2007. Economic weights of fertility, prolificacy, milk yield and longevity in dairy sheep. Animal 1:193-203.

Legaz, E., I. Álvarez, L. J. Royo, I. Fernández, J. P. Gutiérrez, and F. Goyache. 2008. Genetic relationships between Spanish Assaf (Assaf.E) and Spanish native dairy sheep breeds. Small Rumin. Res. 80:39-44.

MAGRAMA. 2013. Ministerio de Agricultura, Alimentación y Medio Ambiente (Spain). Accessed Jan. 2013. http://www.magrama.gob. es/estadistica/pags/anuario/2011/AE_2011_14_01_04_02.pdf.

Mantecón, A. R., P. Díez, B. Villadangos, Y. Martínez, and P. Lavín. 2009. Dairy sheep production systems at the central-north of Spain: Effect of the flock size. Opt. Médit. Sér. A 91:75-77.
Mantecón, A. R., B. Villadangos, P. Díez, Y. Martínez, and P. Lavín. 2006. Gestión económica en ovino de leche. Mundo Ganadero 191:50-56.

Milán, M. J., G. Caja, R. González-González, A. M. Férnández-Pérez, and X. Such. 2011. Structure and performance of Awassi and Assaf dairy sheep farms in northwestern Spain. J. Dairy Sci. 94:771784 .

Morin, E., C. Cassignol, and J. Fraysse. 2004. La Production de Lait de Brebis en France, Diversité des Systèmes d'Exploitation. Collection Résultats, Institut de l'Élevage, Paris, France.

Morin, E., and T. Charroin. 2009. Mise en place d'indicateurs économiques pour la filière française de lait de brebis. Collection Résultats, Institut de l'Élevage, Paris, France.

Riveiro, J. A., A. R. Mantecón, C. J. Álvarez, and P. Lavín. 2013. A typological characterization of dairy Assaf breed sheep farms at NW of Spain based on structural factor. Agric. Syst. 120:27-37.

Rodríguez, L., F. Martínez, E. Herrera, J. Sopena, and M. A. Real. 2002. Gestión técnico económica en explotaciones de ovino de leche en Castilla y León. Aspectos destacables: Campañas 1998, 1999, 2000 y 2001. Pages 462-466 in Proc. XXVII Jornadas Científicas de la Sociedad Española de Ovinotecnia y Caprinotecnia, Valencia, Spain. Servicio de publicaciones, Universidad Cardenal HerreraCEU, Valencia, Spain.

Rodríguez, L., F. Martínez, E. Herrera, J. Sopena, M. A. Real, I. García, R. García, M. García, J. Matilla, M. A. González, J. Padrones, A. Gamarra, and J. I. García. 2003. Gestión técnico económica en explotaciones de ovino de leche en Castilla y León. Aspectos destacables: Campañas 1998-2002. Pages 412-414 in Proc. XXVIII Jornadas Científicas de la Sociedad Española de Ovinotecnia y Caprinotecnia, Badajoz, Spain. Imprenta Diputación, Diputación Provincial de Badajoz, Spain.

Ruiz, R., L. M. Oregui, M. Elgarresta, and S. Marijuan. 2002. Environmental and economic aspects of the dairy sheep system in the Basque Country. Opt. Médit. Sér. B. Etudes et Recherches 39:39-45.

Sánchez, M., J. Gómez, R. Santos, M. J. Gil, and E. de León. 2004. Indicadores económicos financieros de la explotación tipo de ovino lechero COVAP. Pages 342-344 in Proc. XXIX Jornadas Científicas de la Sociedad Española de Ovinotecnia y Caprinotecnia, Lleida, Spain. Imprenta Diputació, Diputació de Lleida, Spain.

Thomas, D. L. 2004. Overview of the dairy sheep sector in Canada and the United States. Pages 6-14 in Proc. 10th Annual Great Lakes Dairy Sheep Symp. Hudson, WI. University of WisconsinMadison.

Tolone, M., V. Riggio, D. O. Maizon, and B. Portolano. 2011. Economic values for production and functional traits in Valle del Belice dairy sheep using profit functions. Small Rumin. Res. 97:41-47.

Toro-Mujica, P., A. García, A. Gómez-Castro, J. Perea, V. RodríguezEstévez, E. Angón, and C. Barba. 2012. Organic dairy sheep farms in south-central Spain: Typologies according to livestock management and economic variables. Small Rumin. Res. 104:28-36.

Toro-Mujica, P., A. García, A. G. Gómez-Castro, R. Acero, J. Perea, V. Rodríguez-Estévez, C. Aguilar, and R. Vera. 2011. Technical efficiency and viability of organic dairy sheep farming systems in a traditional area for sheep production in Spain. Small Rumin. Res. 100:89-95.

Tzouramani, I., A. Sintori, A. Liontakis, P. Karanikolas, and G. Alexopoulos. 2011. An assessment of the economic performance of organic dairy sheep farming in Greece. Livest. Sci. 141:136-142.

Ugarte, E., R. Ruiz, D. Gabiña, and I. Beltrán. 2001. Impact of highyielding foreign breeds on the Spanish dairy sheep industry. Livest. Prod. Sci. 71:3-10.

Wolf, C. A. 2010. Understanding the milk-to-feed price ratio as a proxy for dairy farm profitability. J. Dairy Sci. 93:4942-4948. 